\title{
Torill Strand*
}

\section{A semiotic model of learning}

https://doi.org/10.1515/css-2021-0008

\begin{abstract}
My ambition with this paper is to throw some light on Charles S. Peirce's (1839-1914) semiotic model of learning. Peirce developed this model in his later writings, where he integrated his phenomenology, pragmatism, and semiotics while renewing all three. I start by introducing an analogy on pedagogy used by Peirce in one of his 1903 lectures on phenomenology. Next, I sketch out Peirce's perspective on the ways in which we learn from experience. In the last section, I map out Peirce's semiotic model, while indicating some prospects and limitations of a Peircean outlook on the paradoxical attributions of knowledge and learning.
\end{abstract}

Keywords: experience, Peirce, phenomenology, pragmatism, semiosis

\section{Introduction}

My modest ambition with this short article is to throw some light on Charles S. Peirce's (1839-1914) semiotic model of learning. Peirce developed this model in his later writings, where he integrated his phenomenology, pragmatism and semiotics while renewing all three. Reading these texts, I have asked: How does Peirce portray here the link between lived experience and his more developed semiotics?

It is well known that the philosophy of Charles S. Peirce - "the father of pragmatism" - enhances our understanding of the dynamics of knowledge and learning. Peirce conceives knowledge as "a living historic entity," acquired through experience, mediated through signs, clarified by the pragmatic maxim, and validated by the final consensus. He portrays knowledge as a verb, marked by the communal processes of constructing, reconstructing, and validating beliefs. In his earlier writings, Peirce stressed how the pragmatic principle, the social principle, fallibilism, and abduction should guide processes of inquiry: The pragmatic principle points to the pragmatic maxim as a proposal for achieving clarity of meaning. The social principle recognizes "the ideal perfection of knowledge" through the final consensus. Fallibilism admits the provisional and rectifiable character of opinions and helps to avoid overconfidence in the results by pointing to the trustworthiness of the inferential procedures used. To Peirce, however, the

*Corresponding author: Torill Strand, Department of Education, University of Oslo, Oslo, Norway, e-mail: torill.strand@iped.uio.no 
pragmatic, social, and fallibility principles are valueless if they do not include abduction, which is the principle for creative innovation. "An abduction is a method of forming a general prediction without any positive assurance that it will succeed either in the special case or usually, its justification being that it is the only possible hope of regulating our future conduct rationally" (Peirce 1903: 299). At one analytic level, we may thus characterize a Peircean conception of the dynamics of knowledge and learning as mutual and creative commitments toward shared processes of joint learning (Apel 1995; Strand 2005a, 2005b).

In his later writings, however, Peirce offers a richer conception of productive learning processes (Strand 2013a, 2013b, 2014), as he now establishes an explicit connection between his phenomenology, pragmatism, and semiotics, thus renewing all three. He now develops his early "semiotics" into a more general theory of signs ("semeiotics") and sign use ("semeiosis"), which equates logic in a broad sense. Next, he divides semiotics - "the analytical study of the necessary conditions to which all signs are subject" - into three major divisions. The first of these is speculative grammar, which studies productions and forms of meaning. The second is critic (logic in a narrow sense), which studies how signs may relate to the object, independently of what it represents. In other words, critic examines logical conclusions and arguments. Third, there is speculative rhetoric, which explores the relation between sign and interpretant. "Its most essential business is to ascertain by logical analysis, greatly facilitated by the development of the other branches of semeiotics, what are the indispensable conditions of sign's acting to determine another sign nearly equivalent of itself" (Peirce 1904: 328). Peirce thus argued that speculative rhetoric is "the highest and liveliest branch of logic" as its task is to study the semiotic production of knowledge.

There is an emerging interest in this third discipline of semiotics. Contemporary Peirce scholars clearly demonstrate how Peirce's new rhetoric carries prospects of a fresh outlook on the paradoxical attributions of knowledge and learning (Bergman 2007; Colapietro 2007; Freadman 2004; Kevelson 1984; Liszka 2000; Midtgarden 2005; Santaella-Braga 1999; Short 2007; Strand 2013a, 2013b). Moreover, Peirce's later philosophy appeals to the concerns of contemporary philosophers of education, since it emphasizes the semiotic production of knowledge (Anderson 2005; Bergman 2005, 2013; Chiasson 2001, 2005; Colapietro 2005, 2013; Garrison 2005; Hoffman 2006, 2007; Legg 2017, Liszka 2013; Midtgarden 2005; Paavola and Hakkarainen 2005; Nöth 2010; Pesce 2013; Prawat 1999; Semetsky 2005, 2010, 2017; Stables 2005, 2010; Strand 2005a, 2005b, Strand 2013a, 2013b; Strand and Legg 2019; Ventimiglia 2005). My modest ambition here, however, is just to illustrate how Peirce portrays lived experience in relation to a semiotic model of learning. I start by introducing an analogy on pedagogy used by Peirce in one of his 1903 lectures on phenomenology. Next, I sketch out Peirce's perspective 
on the ways in which we learn from experience. In the last section of this paper, I map out Peirce's semiotic model, while indicating some prospects and limitations of a Peircean outlook on the paradoxical attributions of knowledge and learning.

\section{Experience is our great teacher}

Peirce values learning from experience. He does not undermine learning from reasoning, but argues that "what we are taught by experience is not justified at all: on the contrary, the less it is like previous knowledge, the more valuable an information it is, other things being equal" (Peirce 1911: 454). In stressing the value of how experience violates previous taught, he even contends that

\footnotetext{
In all the works on pedagogy that ever I read, - and that have been many, big, and heavy, - I don't remember that any one has advocated a system of teaching by practical jokes, mostly cruel. That, however, described the method of our great teacher, Experience. She says,

Open your mouth and shut your eyes

And I'll give you something to make wise;
}

And thereupon she keeps her promise, and seems to take her pay in the fun of tormenting us. (Peirce 1903: 154)

Here, Peirce adapts a well-known folk saying, often cited when giving a child a gift of sweets: "Open your mouth and shut your eyes, and I'll give you something to make wise.” With this analogy, Peirce compares experience to a practical joke while claiming that a practical joke, despite its cruelty, may be a good thing.

There seems to be a parallel between Peirce's claim that jokes make us wise, and Aristotle's claim that good riddles convey learning. Peirce speaks about "teaching by practical jokes." Aristotle says that "Good riddles are pleasing [...] for there is learning” (Aristotle 1991 1412a 26). We learn from riddles, since "the very nature indeed of a riddle is this, to describe a fact in an impossible combination of words (which cannot be done with the real names for things, but can be with their metaphorical substitutes) (Aristotle 19921458a 24-29). Metaphors used in riddles provide unexpected and contradictory images, concurrently saying "this is that" and "this is not that." A metaphor is a paradox that surprises, bewilders, and helps to uncover a hidden relation beyond the paradox. The paradoxical attribution of a metaphor may thus convey learning. Aristotle says that learning "occurs when there is a paradox and not, as he [Theodorus] says, in opposition to previous opinion; rather it is like the bogus word coinages in jests" (Aristotle 1991 1412a 33-38). In short, the paradoxical attribution of a riddle first, surprises - as it describes a fact in an unexpected manner; next, it bewilders - as it contests our previous categories of thought; and third, it conveys learning - as it uncovers a relationship hidden beneath the paradox 
(Ricoeur 2003). When speaking of "a system of teaching by practical jokes, mostly cruel," Peirce thus paraphrases Aristotle's way of equating riddles with "the bogus word coinages in jests.”

Peirce, however, moves beyond Aristotle's way of attributing learning to the "impossible combination of words." Peirce attributes learning - as he says - to "the action of experience." He describes this action as a series of surprises:

Your mind was filled with an imaginary object that was expected. At the moment when it was expected the vividness of the representation is exalted, and suddenly when it should come something quite different comes instead. I ask you whether at that instant of surprise there is not a double consciousness, on the one hand of an Ego, which is simply the expected idea suddenly broken off, on the other hand of the Non-Ego, which is the Strange Intruder, in his abrupt entrance. (Peirce 1903: 154)

The surprise is thus in a double consciousness, which is aware on the one hand of the familiar and vivid representations of the expected and on the other hand of the new and unexpected ways of seeing. The surprise is therefore in the relationship between the known and the unknown; between the familiar and the new; or between the "expected idea" and the "strange intruder." The surprise is in the relation between our familiar ways of thinking and something new and unexpected.

In other words, there is a parallel between Aristotle's riddle and Peirce's analogy of the practical joke, because they both articulate truly new things in an unexpected manner. Consequently, both the riddle and the joke bewilder our categories of thought. To Peirce, however, the reason for learning from this bewilderment is the action of experience: Experience is a great teacher because she acts upon our minds and makes us learn. So how should we read this action?

\section{Transactions}

To Peirce, experience is in translations, or rather in transactions. Experience is never pure, never neutral. Experience comes "out of practice"; it is a "forcible modification of our ways of thinking" (Peirce 1904: 370), a "brutally produced conscious effect that contributes to a habit" (Peirce 1907: 399). There is an inescapable rudeness in experience, as experiences unavoidably and compellingly are influencing our ways of being in the world. The course of life thus presents us with this reality: We may lie about our experience, but we can never escape it (Bergman 2007).

Peirce advocates a broad notion of experience. In a letter to William James, he criticizes James' way of limiting experience to sensations and their patterns. He 
writes, “[...] experience and an experiential event are [...] utterly different, experience being the effect that life has produced upon habits" (Peirce 1904: 203). The problem, to Peirce, is that James ignores the interpretational aspects, and thus the ways in which experience acts on our ways of seeing and being in the world: A sensation is not the same thing as an experience, since "experience is the effect that life has produced upon habits." In other words, experience includes interpretations that help to change our habits: "Experience can only mean the total cognitive result of living, and includes interpretations quite as truly as it does the matter of sense" (Peirce 1903: 197).

The best way to read Peirce's distinctive notion of experience is in light of his three phenomenological categories: Firstness, Secondness, and Thirdness. Firstness is pure presence; it is what there is, regardless of anything else. It is the immediate perception of qualities, such as the qualities of feelings or sensations. The pure present, or quality of the color red can here be an example. It is "what stares one in the face, just as it presents itself, unreplaced by any interpretation, unsophisticated by any allowance for this or for that [...]" (Peirce 1903: 147). Secondness is reaction, as it concurrently contains some kind of pure presence and our perception of or reaction to this presence. This may be my fascination over the red color. Immediate perception is always an awareness of a relation. It is a double consciousness that is aware of, on the one hand, the pure and vivid presence and, on the other hand, the perception of it. In this respect, Secondness is "beyond all doubt an irreducible element of thought" (Peirce 1903: 160). However, it does not entail the prospect of learning from experience. Thirdness is transaction, as it "essentially involves the production of effects in the world of existence" (Peirce 1903: 271). Thirdness is triadic, in the sense that it involves three relata: the immediate, incommunicable quality of pure presence; the relation between that quality and my compulsion to notice it; and my conscious conception of the relation between pure presence and my reaction. These could be (1) the color red in a lipstick, (2) my fascination over this particular color, and (3) my description of "a magnificent color.” In Thirdness, we reach the conceptual realm. Thirdness thus entails the prospects of learning, or at least a "sense of personal transformation (of acquiring a new habit or at least of having one's present habits strengthened, refined, or in some other way modified)" (Colapietro 1999: 23). This third category thus elucidates the ways in which experience "is a forcible modification of our ways of thinking" (Peirce 1907: 203).

When Peirce, in his letter to William James, describes experience as "the effect that life has produced upon habits" (Peirce 1904: 203), he points to the significance experience has on our habits. Moreover, we can recognize experience by the ways in which our habits have been transformed. This third category is thus essential to comprehending Peirce's assertion that "Experience is our great Teacher” (Peirce 
1903: 194). However, while experiences teach, signs are the only means of learning we have. So with that in mind, let us look at how Peirce portrays the relation between lived experience and semiotic learning.

\section{A semiotic model of learning}

The point of departure of Peirce's semiotics - which is the study of the action of signs and sign-systems - is the axiom that cognition, thought, and even humans are semiotic in their essence. Thoughts are in signs, and like a sign, a thought refers to other thoughts and to objects in the world. The most central concepts of semiotics are "sign" and "semiosis."

A sign is concurrently a medium and a mediator, a representation which itself is "an element of the Phenomenon" (Peirce 1903: 160). Its most characteristic feature is its triadic structure that, drawing on Peirce's key notion of Thirdness as "transaction," identifies every sign as a medium of both communication and creation (Strand and Legg 2019).

"I will say that a sign is anything, of whatsoever mode of being, which mediates between an object and an interpretant, since it is both determined by the object relatively to the interpretant, and determines the interpretant in reference to the object, in such a wise as to cause the interpretant to be determined by the object through the mediation of this "sign" (Peirce 1907: 410).

The mediating structure is the triadic relation of sign, object, and "interpretant." For instance, in the case of the red lipstick, the sign is the words used to describe the red color, the object is the lipstick's characteristic color, and the interpretant consists in all the ways we tend to use the same words to describe that characteristic color. This example clearly illustrates the way in which a sign simultaneously is a "medium of communication" (Peirce 1903: 239) and creation. Because if, in the case of the characteristic red color on that lipstick, the process of sign-use continues, the sign can be said to be "living" not only in a metaphorical sense.

At one analytical level, we may describe learning processes as processes of sign-interpretations that spread among sign-users insofar as they succeed at making the world more comprehensible. Such processes include all kinds of sign relations in which each relation is part of a complicated network of interpretations and interactive systems of actions where each process gives birth to one or several new processes. In other words, the dynamics of knowledge and learning are in the flow of signs that "presses upon every one of us daily and hourly" (Peirce 1907: 410). These actions of signs are "semiosis." 
"By semeiosis I mean an action, or influence, which is, or involves, a cooperation of three subjects, such as a sign, its object, and its interpretant, this trirelative influence not being in any way resolvable into actions between pairs" (Peirce 1907: 411).

Peirce's notion of "semiosis" - the action of signs - highlights the power of signs to move agents and eventually to change their habits. This potentiality crucially involves Thirdness, because "no sign ever acts as such without producing a physical replica of interpreting sign” (Peirce 1903: 271). Consequently, semiosis is an intelligent, triadic action.

\section{Semiosis as a root metaphor}

To philosophy of education, Peirce offers an alternative metaphor of mind and cognition that challenges much mainstream thinking. To Peirce, thoughts are in the flow of signs, and like a flow of signs, a thought refers to other thoughts and to objects in a world of change: We understand the world through signs; signs are our means of thinking about relations and objects. Signs give access to the local/global semeiosphere in which we live and work; to the historically produced knowledge repertoire of our culture; and to the fast flows of information and communication distributed through social media and virtual networks (Lotman 1991; Strand 2014; Strand and Legg 2019). Our understanding of the world is therefore always mediated through historically based and virtual signs, and thus by the referential domain they bring about between our mind and our local/global semeiosphere. Moreover, signs have the power to move agents and to change their habits. In short, the dynamics of knowledge and learning are in signs. However, for these dynamics to be productive, sign processes have to be embodied. Next, the conscious effects of such processes should be subject to self-control and pragmatic examination. Consequently, learning is a semiotic process.

In sum, Peirce's semiotic is a broad logic, offering an alternative metaphor of mind and cognition, emphasizing the knowledge-generating processes themselves. To philosophy of education, Peirce's later philosophy thus invites a shift in perspective from the anthropocentric processes of joint learning processes towards the semiotic processes that characterize meaning productions and the growth of knowledge itself. Therefore, we should not read Peirce's later philosophy as a more or less formalistic theory of signs or a technique for studying them, but rather as a highly sophisticated philosophical perspective on signs and semiosis. Nor does Peirce's philosophy offer a theory of experiential learning, a didactics of experiential pedagogy, or an "edu-semiotic" method of teaching. What Peirce offers is 
simply a sophisticated framework for further philosophical and epistemological deliberations on the semiotic growth of knowledge.

\section{References}

Anderson, Doug. 2005. Peirce and the art of reasoning. Studies in Philosophy and Education 24(3-4). 277-289.

Apel, Karl-Otto. 1995. Charles S. Peirce. From pragmatism to pragmaticism. New Jersey: Humanities Press.

Aristotle. 1991. On rhetoric. Translated, with introduction. Edited by George A. Kennedy. New York: Oxford University Press.

Aristotle. 1992. Poetics. Edited by Richard McKeon. New York: The Modern Library.

Bergman, Mats. 2005. C. S. Peirce's dialogical conception of sign processes. Studies in Philosophy and Education 24(3-4). 213-233.

Bergman, Mats. 2007. The secret of rendering signs effective: The import of C. S. Peirce's semiotic rhetoric. The Public Journal of Semiotics 1(2). 2-11.

Bergman, Mats. 2013. Fields of rhetoric: Inquiry, communication, and learning. Educational Philosophy and Theory 45(7). 737-754.

Chiasson, Phyllis. 2001. Peirce and educational philosophy. In Digital encyclopedia of Charles $S$. Peirce, January. Available at: http://www.digitalpeirce.fee.unicamp.br/educhi.htm (accessed 5 June 2020).

Chiasson, Phyllis. 2005. Peirce's design for thinking: An embedded philosophy of education. Educational Philosophy and Theory 37(2). 207-226.

Colapietro, Vincent. 1999. Peirce's guess at the riddle of rationality: Deliberative imagination as the personal locus of human practice. In Sandra Rosenthal, Carl R. Hausman \& Douglas R. Anderson (eds.), Classical American pragmatism. Its contemporary vitality, 15-30. Urbana and Chicago: University of Illinois Press.

Colapietro, Vincent. 2005. Cultivating the arts of inquiry, interpretation, and criticism: A Peircean approach to our educational practices. Studies in Philosophy and Education 24(3-4). 337-366.

Colapietro, Vincent. 2007. C. S. Peirce's rhetorical turn. Transactions of the Charles S. Peirce Society 43(1). 16-52.

Colapietro, Vincent. 2013. Neglected facets of Peirce's speculative rhetoric. Educational Philosophy and Theory 45(7). 712-736.

Freadman, Anne. 2004. The machinery of talk. Charles Peirce and the sign hypothesis. Stanford, CA: Stanford University Press.

Garrison, Jim. 2005. Curriculum, critical common-sensism, scholasticism, and the growth of democratic character. Studies in Philosophy and Education 24(3-4). 179-211.

Hoffman, Michael H. G. 2006. What is a "semiotic perspective", and what could it be? Educational Studies in Mathematics 61(1-2). 279-291.

Hoffman, Michael H. G. 2007. Learning from people, things, and signs. Studies in Philosophy and Education 26(3). 185-204.

Kevelson, Roberta. 1984. C. S. Peirce's speculative rhetoric. Philosophy and Rhetoric 17(1). 16-29.

Legg, Cathy. 2017. Diagrammatic teaching: The role of iconic signs in meaningful pedagogy. In Inna Semetsky (ed.), Edusemiotics. A handbook, 29-25. Singapore: Springer. 
Liszka, James Jakób. 2000. Peirce's new rhetoric. Transactions of the Charles S. Peirce Society 36(4). 439-476.

Liszka, James Jakób. 2013. Charles Peirce's rhetoric and the pedagogy of active learning. Educational Philosophy and Theory 45(7). 781-788.

Lotman, Yuri. 1991. Universe of the mind. A semiotic theory of culture. Bloomington: Indiana University Press.

Midtgarden, Torjus. 2005. On the prospects of a semiotic theory of learning. Educational Philosophy and Theory 37(2). 239-252.

Nöth, Winfried. 2010. The semiotics of teaching and the teaching of semiotics. In Inna Semetsky (ed.), Semiotics, education, experience, 1-19. Rotterdam: Sense publishers.

Paavola, Saami \& Kai Hakkarainen. 2005. Three abductive solutions to the Meno paradox - with instinct, inference, and distributed cognition. Studies in Philosophy and Education 24(3-4). 235-253.

Peirce, Charles Sanders. 1998 [1904]. Ideas, stray and stolen, about scientific writing. In The Peirce Edition Project (ed.), The essential Peirce. Selected philosophical writings, vol. 2 (1893-1913), 325-330. Bloomington, IN: Indiana University Press.

Peirce, Charles Sanders. 1998 [1907]. Pragmatism. In The Peirce Edition Project (ed.), The essential Peirce. Selected philosophical writings, vol. 2 (1893-1913), 398-433. Bloomington, IN: Indiana University Press.

Peirce, Charles Sanders. 1998 [1911]. A sketch of logical critics. In The Peirce Edition Project (ed.), The essential Peirce. Selected philosophical writings, vol. 2 (1893-1913), 451-462. Bloomington, IN: Indiana University Press.

Peirce, Charles Sanders. 1998 [1903]. Harvard lectures on pragmatism. In The Peirce Edition Project (ed.), The essential Peirce. Selected philosophical writings, vol. 2 (1893-1913), 133-241. Bloomington, IN: Indiana University Press.

Pesce, Sebastién. 2013. From Peirce's speculative rhetoric to educational rhetoric. Educational Philosophy and Theory 45(7). 755-780.

Prawat, Richard S. 1999. Dewey, Peirce, and the learning paradox. American Educational Research Journal 36(1). 47-76.

Ricoeur, Paul. 2003. The rule of metaphor. The creation of meaning in language. London: Routledge.

Santaella-Braga, Louise. 1999. Methodeutics, the liveliest branch of semiotics. Semiotics 124(3-4). 377-395.

Semetsky, Inna. 2005. Peirce's semiotics, subdoxastic, aboutness, and the paradox of inquiry. Educational Philosophy and Theory 37(2). 227-238.

Semetsky, Inna (ed.). 2010. Semiotics, education, experience. Rotterdam: Sense publishers.

Semetsky, Inna (ed.). 2017. Edusemiotics. A handbook. Singapore: Springer.

Short, Thomas Lloyd. 2007. Peirce's theory of signs. Cambridge: Cambridge University Press.

Stables, Andrew. 2005. Living and learning as semiotic engagement. A new theory of education. Lewiston: The Edwin Mellen Press.

Stables, Andrew. 2010. Semiosis and the collapse of mind-body dualism. In Inna Semetsky (ed.), Semiotics, education, experience, 21-36. Rotterdam: Sense publishers.

Strand, Torill. 2005a. Peirce on educational beliefs. Studies in Philosophy and Education 24(3-4). 255-276.

Strand, Torill. 2005b. Peirce on education: Nurturing the first rule of reason. Studies in Philosophy and Education 24(3-4). 309-316. 
Strand, Torill. 2013a. Peirce's new rhetoric. Prospects for educational theory and research. Educational Philosophy and Theory 45(7). 707-711.

Strand, Torill. 2013b. Peirce's rhetorical turn. Conceptualising education as semiosis. Educational Philosophy and Theory 45(7). 789-803.

Strand, Torill. 2014. 'Experience is our great and only teacher': A Peircean reading of Wim Wenders' Wings of Desire. Journal of Philosophy of Education 48(3). 433-445.

Strand, Torill \& Cathy Legg. 2019. Peirce and education, an overview. In Michael A. Peters (ed.), Encyclopedia of educational philosophy and theory. Singapore: Springer Nature.

Ventimiglia, Michael. 2005. Three educational orientations: A Peircean perspective on education and the growth of self. Studies in Philosophy and Education 24(3-4). 291-308.

\section{Bionote}

\section{Torill Strand}

Torill Strand (b. 1957) is a professor at the University of Oslo. Her research interests include political philosophy of education, educational philosophy and theory, cosmopolitanism, and semiotics. Her recent publications include Peirce and education (2019), Rethinking ethicalpolitical education. Beyond the Nordic Model (2020), Cinema \& philosophy - some notes on the educational aspects (2020), and Alain Badiou and education (2020). 